$\mathrm{Nr} 6$

KRAKÓw 2003

\section{MARIA TKOCZ}

Uniwersytet Śląski, Katowice
WARSZAWA-

\title{
Przejawy procesu globalizacji w przemyśle województwa śląskiego
}

Globalizacja jest ostatnio modnym i nośnym terminem obecnym w pracach każdego, kto zajmuje się sprawami współczesnego świata. Świadczą o tym zaczerpnięte z różnych opracowań określenia, takie jak „globalna wioska”, „globalne społeczeństwo”, „globalna gospodarka”, ,globalny przemysł” itp. Nie wyjaśniają one jednak zakresu pojęcia „globalizacja". Mimo istnienia różnych definicji, żadna nie jest powszechnie akceptowana.

Za jedną z najbardziej trafnie odzwierciedlających zjawisko globalizacji należy uznać definicję A. Giddensa (1997), który globalizację traktuje jako

intensyfikację stosunków społecznych o światowym zasięgu, która łączy różne lokalności w ten sposób, że lokalne wydarzenia kształtowane są przez zdarzenia zachodzące w odległości wielu tysięcy mil i same zwrotnie na nie oddziałują.

Podobnie sądzi wielu innych autorów, np. A. McGrew (1992), według którego globalizacja polega „na wielości powiązań i wzajemności oddziaływań państw i społeczeństw tworzących obecny światowy system" (Zorska 1998).

Są to definicje nakreślające ogólne ramy procesu globalizacji. Za bardziej odpowiadające przedmiotowi zainteresowań geografii ekonomicznej należy uznać definicje ekonomistów, np. G. Kołodko (2001). Według niego:

globalizacja to proces tworzenia się zliberalizowanego i zintegrowanego światowego rynku towarów i kapitału oraz kształtowanie się nowego międzynarodowego ładu instytucjonalnego służącego rozwojowi produkcji, handlu i przepływów finansowych na skalę całego świata.

Podobne poglądy prezentuje A. Zorska (1998, s. 20). Według niej:

globalizacja gospodarki to dokonujący się na świecie długofalowy proces integrowania coraz większej liczby krajowych gospodarek ponad ich granicami, dzięki rozszerzaniu się oraz intensyfikowaniu wzajemnych powiązań (inwestycyjnych, produkcyjnych, handlowych, kooperacyjnych), w wyniku czego powstaje ogólnoświatowy system ekonomiczny o dużej współzależności i znaczących reperkusjach działań podejmowanych nawet w odległych krajach.

Generalnie, można przyjąć za L. Thurowem (1998), że globalizacja gospodarcza oznacza proces przekształcenia oddzielnych gospodarek narodowych w zintegrowaną gospodarkę światową. Głównymi siłami napędowymi globalizacji stały się wielkie transnarodowe korporacje, korzystające z synergicznego działania kilku kluczowych elementów, takich jak zmiany technologiczne, a zwłaszcza wykorzystywanie rewolucji informatycznej 
do prowadzenia globalnych interesów, liberalizacja handlu i znoszenie barier w przepływach towarów, usług, inwestycji zagranicznych, deregulacja rynków finansowych, a także rosnąca łatwość, a zarazem malejące relatywnie koszty transportu i komunikacji, określane jako tzw. kurczenie się czasu i przestrzeni, co niektórzy określają nawet mianem „końca geografii”".

Oprócz wielkich transnarodowych korporacji duże znaczenie w procesie globalizacji mają organizacje pozarządowe, jak Międzynarodowy Fundusz Walutowy (MFW), Bank Światowy (WB) czy Światowa Organizacja Handlu (WTO). Pierwsze dwie organizacje udzielają pożyczek krajom na programy strukturalne i dostosowanie ukierunkowane głównie na eksport, zaś głównym celem WTO jest liberalizacja międzynarodowego handlu. Organizacje te w ostatnich latach spotykają się z ostrą krytyką ze strony ruchów antyglobalistycznych.

W świetle przedstawionych powyżej poglądów celem niniejszego artykułu jest przedstawienie wybranych aspektów procesu globalizacji w województwie śląskim i odpowiedź na pytanie: czy i w jakim stopniu gospodarka śląska, a zwłaszcza przemysł włącza się w ów proces integracji gospodarki światowej?

Egzemplifikacją tego procesu jest ekspansja i rozwój działalności transnarodowych korporacji, określanych również jako grupy kapitałowe, w województwie śląskim.

\section{OGÓLNA CHARAKTERYSTYKA WOJ. ŚLĄSKIEGO}

Województwo śląskie w aktualnych granicach jest obszarem o dużym zróżnicowaniu gospodarczym. Rozwinęły się tu trzy okręgi przemysłowe (Górnośląski, Częstochowski i Bielski) o zróżnicowanej strukturze gałęziowej, charakteryzujące się jednak znacznym udziałem gałęzi tradycyjnych, tj. górnictwa i hutnictwa, przemysłu włókienniczego i maszynowego. Województwo zamieszkuje 4,8 mln osób, czyli 12,5\% mieszkańców Polski (2000 r.). Jest to województwo najwyżej zurbanizowane (79,3\%), o wysokiej gęstości zaludnienia sięgającej 394 osób na km² . Liczba pracujących wynosiła w 2000 roku 1751 tys. osób, tj. 11,5\% pracujących w kraju. W przemyśle zaś pracowało 537,6 tys. osób, tj. 17,2\% pracujących w przemyśle Polski.

Problem bezrobocia dotknął także to województwo. Zarejestrowanych bezrobotnych było 260 tys. (2000 r.), tj. 9,6\% w skali kraju, a stopa bezrobocia wynosiła 12,9\%. W województwie funkcjonowało 385,4 tys. podmiotów gospodarczych, w tym 309 przedsiębiorstw państwowych oraz 344 tys. podmiotów osób fizycznych i spółek cywilnych. Spółek prawa handlowego $\mathrm{z}$ udziałem kapitału zagranicznego było 3713, tj. 8,5\% w skali kraju.

Odsetek podmiotów z kapitałem zagranicznym jest w Śląskiem nieproporcjonalnie niski w porównaniu z potencjałem ludnościowym. Nie jest to jednak jedyne kryterium udziału kapitału zagranicznego w gospodarce. Istotniejszym miernikiem może być wielkość zainwestowanego kapitału. Pod tym względem - według B. Domańskiego (2001) - woj. śląskie, w którym zainwestowano do 1999 r. 3,4 mld USD, ustępowało jedynie mazowieckiemu (4,1 mld USD).

Zainteresowanie regionem przez światowe firmy w początkowych latach transformacji było słabe.

Przyczyn tego stanu rzeczy należy doszukiwać się między innymi w: 
-stanie struktury wytwórczości regionu zdominowanej przez tradycyjne, surowcowe i przestarzałe gałęzie przemysłu,

- pozostawieniu gospodarki regionu działaniom praw rynku, przy jednoczesnym interwencjonizmie w zakresie cen węgla,

- braku kompleksowego programu restrukturyzacji,

- silnej pozycji związków zawodowych,

- silnej pozycji „lobby” górniczo-hutniczego, hamującego zmiany,

- nadmiernym zatrudnieniu i związaną z tym niską wydajnością pracy,

-kreowaniu negatywnego wizerunku regionu.

Wobec przedstawionych przyczyn wielkie transnarodowe korporacje przyjęły postawę „wyczekiwania” na korzystniejsze warunki wkraczania na rynek.

\section{SPOSOBY WŁĄCZANIA PRZEMYSŁU WOJ. ŚLĄSKIEGO W GOSPODARKĘ ŚWIATOWA}

Możliwości włączenia się gospodarki w system globalny jest wiele (ryc. 1). Przedstawione zostały m.in. w pracy T. Stryjakiewicza (1999).

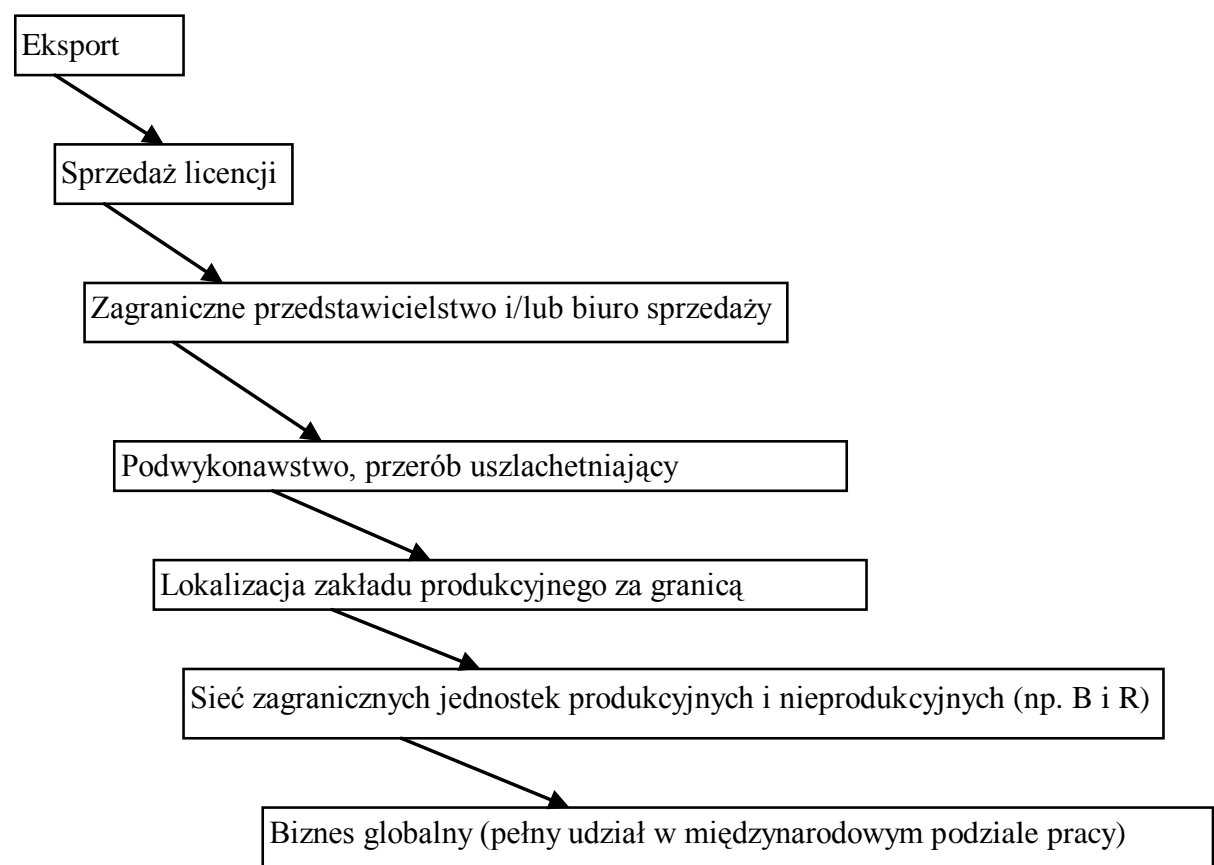

Ryc. 1. Typowa ścieżka rozwoju przedsiębiorstwa wielonarodowego (wg Stryjakiewicz 1999) 
Województwo śląskie stosunkowo wcześnie włączyło się w proces umiędzynarodowienia gospodarki, bowiem już w latach 70. jeden z czołowych światowych koncernów włoski Fiat udostępnił swoją licencję Fabryce Samochodów Małolitrażowych w Tychach.

Natomiast w pierwszych latach transformacji światowe firmy wkroczyły na peryferia regionu kupując zakłady o orientacji rynkowej, jak zakłady chemii gospodarczej w Raciborzu zakupione przez firmę Henkel, czy zakłady gazów technicznych zakupione przez światowych potentatów w tej dziedzinie, jak BOC, Linde, Liquid Carbonic, które stały się właścicielami zakładów w Siewierzu, Pszczynie i Gliwicach. W ten sposób realizowany był jeden z podstawowych celów prywatyzacji, tj. uzyskanie dostępu do nowych technologii. Wymienione firmy światowe ten postulat w pewnym stopniu zrealizowały. Na marginesie można stwierdzić, że w tym początkowym okresie procesu transformacji włączenie gospodarki regionu w gospodarkę światową polegało między innymi na przeniesieniu zużytego acz jeszcze funkcjonującego sprzętu z zakładów Europy Zachodniej do Polski. Przykładem może być działalność korporacji BOC, która zainwestowała w zakupiony zakład gazów technicznych w Siewierzu poprzez przeniesienie do niego z Wielkiej Brytanii wysłużonych ok. 40-letnich sprężarek acetylenowych firmy „Sager”. W podobny sposób wiele korporacji wprowadzało „nowe technologie” w Polsce.

W 1992 r. przemysł regionu został włączony w globalną sieć przemysłu motoryzacyjnego. Stało się to za sprawą korporacji Fiat, która przejęła zakłady w Tychach i BielskuBiałej. Wraz z wejściem Fiata, włoskie spółki wchodzące w skład globalnego koncernu „Fiat Group” zainwestowały w przemysł motoryzacyjny regionu. Spółka „Magneti Marelli”, w której Fiat posiada większość udziałów, dysponuje 52 zakładami produkcyjnymi w 14 krajach, m.in. w Stanach Zjednoczonych, Meksyku, Brazylii, Argentynie, Turcji, Indiach i Niemczech. Spółka ta specjalizuje się w produkcji komponentów do samochodów, jak: systemy zasilania w paliwo, lusterka, skrzynie biegów, reflektory, systemy klimatyzacyjne. Zainwestowała ona $60 \mathrm{mln}$ dolarów w zakład w Sosnowcu, a połączona fuzją z tą spółką firma Gilardinii produkująca systemy wydechowe dla samochodów, zainwestowała w Dąbrowie Górniczej. Firmy te dostarczają 47\% swej produkcji do korporacji Fiat, $43 \%$ do firm samochodowych na całym świecie, a 10\% do innych przedsiębiorstw.

Z Fiatem związana jest także spółka „Teksid”, kontrolowana przez Fiata od 1978 r. i posiadająca zakłady zlokalizowane we Włoszech, Portugalii, Francji, Turcji, Kanadzie, Stanach Zjednoczonych, Brazylii, Argentynie i Chinach. Teksid specjalizuje się w produkcji komponentów z żeliwa, aluminium, magnezu, takich jak: korpusy silników, szkielety siedzeń, wały silników itp. Przejął on zakłady w Skoczowie i Bielsku-Białej. Odbiorcami produktów tej spółki są w 32\% zakłady należące do korporacji Fiat, reszta kierowana jest do innych odbiorców przemysłu motoryzacyjnego na całym świecie, w tym do prawie wszystkich światowych producentów samochodowych. Można zatem stwierdzić, że w zakresie powiązań motoryzacyjnych istniejących w ramach Fiata śląskie zakłady włączone zostały w globalną sieć produkcji.

Przedstawione inwestycje w produkcję samochodową, a przede wszystkim wzrost popytu na samochody stały się czynnikiem lokalizacji kolejnych dużych inwestycji w tej branży. Inwestycje te zbiegły się z utworzeniem w 1996 r. katowickiej specjalnej strefy ekonomicznej składającej się z 4 podstref: gliwickiej, sosnowiecko-dąbrowskiej, tyskiej, jastrzębsko-żorskiej. W 1999 r. do strefy włączono tereny zakładu Fiata w Bielsku-Białej i niezagospodarowane tereny zlikwidowanej częstochowskiej specjalnej strefy ekonomicznej (tab. 1). 
Ogółem katowicka strefa obejmuje ponad 20 różnych obszarów, co umożliwia inwestorom wybór najdogodniejszej lokalizacji. Większość obszarów znajduje się w pobliżu międzynarodowych tras wschód-zachód (Lwów-Wrocław-Berlin) i północ-południe (Gdańsk-Cieszyn-Bratysława) oraz planowanych autostrad A1 i A4.

Tabela 1. Inwestycje zagraniczne w katowickiej specjalnej strefie ekonomicznej

\begin{tabular}{|l|c|c|c|c|c|c|}
\hline & \multirow{2}{*}{$\begin{array}{c}\text { Powierzchnia } \\
\text { Nazwa podstrefy } \\
\text { (ha) }\end{array}$} & Ogółem (ha) & $\begin{array}{c}\text { Obszar zagospodarowany } \\
\text { zagraniczne } \\
\text { w \% }\end{array}$ & $\begin{array}{c}\text { Inwestycje } \\
\text { w tys. zł }\end{array}$ & $\begin{array}{c}\text { Ilość } \\
\text { inwesty- } \\
\text { cji zagra- } \\
\text { nicznych }\end{array}$ & $\begin{array}{c}\text { Liczba } \\
\text { zatrud- } \\
\text { nionych } \\
\text { osób }\end{array}$ \\
\hline gliwicka & 349 & 225,29 & 72 & 1687,657 & 19 & 5370 \\
\hline $\begin{array}{l}\text { jastrzębsko- } \\
\text {-żorska }\end{array}$ & 206,3 & 64,7 & 46 & 580,709 & 5 & 984 \\
\hline $\begin{array}{l}\text { sosnowiecko- } \\
\text {-dąbrowska }\end{array}$ & 310 & 97,5 & 78 & 961,218 & 11 & 1266 \\
\hline tyska & 136 & 103,21 & 83 & 694,339 & 9 & 2396 \\
\hline Razem & 1001,3 & 490,41 & & 3923,923 & 44 & 10016 \\
\hline
\end{tabular}

Źródło: Informator KSSE

Katowicka SSE jest liderem wśród polskich stref pod względem wielkości inwestycji. Jej największą inwestycją typu greenfield jest fabryka samochodów Opel, koncernu General Motors. Firma ta stała się magnesem przyciąającym kolejnych inwestorów. Zatrudnia 2000 osób, a wartość inwestycji sięgnęła 1,2 mld zł.

Lokalizacja w regionie dwóch dużych fabryk samochodowych czołowych światowych firm przyciągnęła inne zagraniczne spółki pracujące na rzecz przemysłu światowego, które zbudowały tu swoje nowe zakłady (tab. 2). Należą do nich:

- Isuzu Motors - jeden z największych producentów silników na świecie, który zainwestował w tyskiej strefie ponad $400 \mathrm{mln}$ zł i zatrudnia ok. 350 osób. Produkcja zakładu kierowana jest nie tylko do firm samochodowych zlokalizowanych w Polsce, ale i w całej Europie;

- Delphi Automotiv Systems z USA - zainwestował w produkcję przekładni dla przemysłu samochodowego $100 \mathrm{mln}$ zł i zatrudnia 200 osób;

- Lear Corporation - specjalizujący się w produkcji siedzeń samochodowych dla Fiata, zainwestował $78 \mathrm{mln}$ zł i zatrudnia ok. 500 osób.

Tabela 2. Najwięksi inwestorzy zagraniczni w katowickiej specjalnej strefie ekonomicznej

\begin{tabular}{|c|l|c|l|l|}
\hline $\mathrm{Nr}$ & \multicolumn{1}{|c|}{ Inwestor } & $\begin{array}{c}\text { Kapitał } \\
\text { zainwestowany } \\
\text { (w tys. PLN) }\end{array}$ & $\begin{array}{c}\text { Kraj } \\
\text { pochodzenia }\end{array}$ & \multicolumn{1}{|c|}{ Branża } \\
\hline 1 & General Motors OPEL Polska & 1172078 & USA & samochodowa \\
2 & Guardian Industries Poland & 442404 & USA & szklarska \\
3 & Isuzu Motors Sp. z o.o. & 422094 & Japonia & samochodowa \\
4 & Power Train & 410000 & Włochy & samochodowa \\
5 & Pol-Disc Strefa Sp. z o.o. & 138000 & Włochy & samochodowa \\
6 & 3-T Optical Media Sp. z o.o. & 103761 & Szwajcaria & elektrotechniczna \\
7 & Ekocem Sp. z o.o. & 100400 & Niemcy & mineralna \\
8 & Delphi Automative System Sp. z o.o. & 1005 & USA & samochodowa \\
\hline
\end{tabular}




\begin{tabular}{|r|l|l|l|l|}
\hline 9 & Poland 22 Bussines Park & 87375 & USA & usługi \\
10 & Silesia Sp. z o.o. & 78050 & Hiszpania & mineralna \\
\hline
\end{tabular}

Źródło: Opracowanie własne na podstawie materiałów z Informatora KSSE

Brytyjsko-amerykański koncern TRW uruchomił produkcję w dwóch firmach, z których Lucas Varity specjalizuje się w tarczach hamulcowych, a Teneco w amortyzatorach i tłumikach. Zainwestował około $80 \mathrm{mln}$ zł i zatrudnia 200 osób.

Spółka Power Train o wspólnym udziale Fiata i General Motors produkuje w Bielsku silniki wysokoprężne, a Manuli Auto Polska specjalizuje się w elementach klimatyzacyjnych. Oprócz Isuzu inwestycje japońskie reprezentuje także firma Toyo Seal produkująca uszczelki do łożysk.

Są to firmy międzynarodowe, które produkując w Polsce dla światowych koncernów samochodowych, mających swe zakłady w różnych częściach świata, włączają się w globalną sieć powiązań. Można uznać, że w dziedzinie przemysłu samochodowego woj. śląskie zostało włączone w zintegrowaną gospodarkę światową.

Udział branży samochodowej w katowickiej strefie wynosi ok. 60\%. Inwestycje związane z tą branżą znajdują się także poza strefą, m.in. w Czechowicach-Dziedzicach, Jeleśni. Można przyjąć, że przemysł ten jest podstawowym stymulatorem rozwoju w regionie poprzez generowanie rozległych efektów mnożnikowych.

Drugą branżą, która włącza się w światową sieć powiązań jest przemysł szklarski. W katowickiej strefie zainwestowano w niego 14\% kapitału. Czołową inwestycją jest huta szkła amerykańskiego koncernu Guardian, na terenie huty Częstochowa. Koncern zainwestował $400 \mathrm{mln}$ zł i wprowadził najnowocześniejszą technologię produkcji szkła, polegającą na wylewaniu masy szklanej na duże formy z roztopioną cyną, która nadaje produkowanemu szkłu najwyższą jakość. Zakład w Częstochowie jest częścią oddziału Guardian Europe z siedzibą w Luksemburgu, który dysponuje 6 hutami w Europie: w Luksemburgu, Hiszpanii, Niemczech i na Węgrzech oraz 21 w świecie.

Branżę szklarską reprezentuje także luksemburska inwestycja firmy Vitrum i holenderska Vetrad. Poza strefą zainwestowała francuska firma St. Gobain, budując w Dąbrowie Górniczej inwestycję typu greenfield w 1997 r. za $500 \mathrm{mln}$ zł oraz przejmując i modernizując zakład szyb zespolonych w Żorach. Mimo iż St. Gobain w Dąbrowie Górniczej należy do największych firm światowych, produkcja szkła ze względu na specyfikę produkcji przeznaczona jest głównie na rynek krajowy, eksport sięga maksymalnie $25 \%$. Koncern zajmuje się także produkcją wełny szklanej w Gliwicach, zaś niemiecki Pfeiderer buduje zakład wełny szklanej w Dąbrowie Górniczej.

O ile w przypadku firm samochodowych możemy mówić o produkcji finalnej przeznaczonej na rynek światowy, to w przypadku przemysłu szklarskiego powiązania globalne dotyczą kapitału, a przede wszystkim technologii.

Podobny charakter mają inwestycje światowych firm w produkcję gazów technicznych, które ze względu na specyfikę produktu nie nadają się na eksport, a ich rozmieszczenie nawiązuje do głównych odbiorców. Stąd powiązania z globalną siecią producentów obejmuja głównie korzystanie z najnowszych technologii, zaś gazy wykorzystywane są na miejscu. Do takich inwestycji należą tlenownie wybudowane na terenach hut stali w Gliwicach (BOC) i Zawierciu (Air Products). Dużą inwestycją w tym zakresie była także budowa nowoczesnej instalacji tlenowej przy Hucie Katowice, w miejsce starej konstrukcji radzieckiej z lat 60. Nowa instalacja może produkować 1600 ton tlenu na dobę i jest przy- 
gotowana na pełne zaspokojenie ewentualnie zwiększonych potrzeb Huty Katowice w tlen, argon, azot. Jest to największa tego typu instalacja w Polsce. Francuski koncern Air Liquide, który obsługuje 30\% rynku gazów technicznych w Europie, 29\% w obu Amerykach, 14\% w Azji i krajach Pacyfiku i 2\% w Afryce, zainwestował łącznie ok. 200 mln franków. Do światowych producentów gazów technicznych należy także niemiecki Messer Griesheim, który w 1999 r. uruchomił nową acetylenownię w Chorzowie.

Poprzez działalność międzynarodowych korporacji Polska włącza się w międzynarodowy system kredytowania, bowiem wiele inwestycji kredytuje Europejski Bank Rozbudowy i Rozwoju oraz banki państw inwestorów zagranicznych.

Spośród innych międzynarodowych firm, które zainwestowały w przemysł woj. śląskiego należy wymienić:

1) niemiecki Ekocem, który zainwestował $150 \mathrm{mln}$ zł w produkcję cementu wykorzystując do produkcji żużel odpadowy;

2) włoską firmę Mapei, która posiada 19 zakładów w Europie, Ameryce Północnej i Południowej, Azji i Autralii i specjalizuje się w produkcji klei do płytek ceramicznych oraz dodatków do zapraw,

3) szwedzką firmę Atlas-Copco, która zainwestowała w produkcję klei,

4) hiszpańską firmę Roca, która uruchomiła produkcję ceramiki sanitarnej w zakładzie ZWS ,Silesia”.

Są to zakłady o orientacji rynkowej, których głównym czynnikiem lokalizacji w regionie śląskim było zdobycie nowych rynków zbytu.

Podobny charakter mają inwestycje w branży spożywczej. Należy tu wymienić Pepsico, które zainwestowało w produkcję wody mineralnej w Żywcu, Heineken w produkcję piwa i słodu w Żywcu, Cieszynie, Bielsku, Unilever w zakłady tłuszczu w Katowicach, Kraft Jakobs Suchard w zakłady Olza w Cieszynie, Danon w zakłady serów w Tychach oraz South African Breweries z RPA w produkcje piwa w Tychach.

Przedstawione przykłady wskazują na znaczne ,zglobalizowanie” przemysłu woj. śląskiego. Według PAIZ woj. śląskie jest aktualnie, obok mazowieckiego (17\%), obszarem o najwyższej aktywizacji inwestycyjnej (14\%). Jego atrakcyjność inwestycyjna będzie procesem ciagłym. Przykładowo włoski Fiat zaplanował zainwestowanie prawie $815 \mathrm{mln}$ USD, Browary Południowoafrykańskie $40 \mathrm{mln}$ USD, BOC $60 \mathrm{mln}$ USD.

Przedstawione przykłady wskazują na duże zainteresowanie firm światowych województwem śląskim, traktując go zwłaszcza w aspekcie dużego potencjału demograficznego i gospodarczego jako potencjalny duży rynek zbytu dla swych wyrobów. Spośród przedstawionych przykładów większość inwestycji ma orientację popytową, która zaspokaja potrzeby mieszkańców bądź innych branż przemysłu o charakterze konsumenckim. Brak jest natomiast inwestycji w nowoczesne branże i technologie.

\section{INWESTYCJE ZAGRANICZNE WEDŁUG KRAJU POCHODZENIA KAPITAŁU}

W literaturze przedmiotu rozpowszechniony jest pogląd, że obecny etap globalizacji to przede wszystkim ,amerykanizacja”. Dzisiejszą lokomotywą globalizacji według 
J. Greya (Kołodko 2001) są Stany Zjednoczone, co wiąże się z dominacją tego państwa w gospodarce światowej, kulturze i polityce. Czy dominacja Stanów Zjednoczonych znajduje również odzwierciedlenie w procesie globalizacji woj. śląskiego?

Odpowiedzią na to pytanie może być analiza wielkości napływu kapitału do katowickiej specjalnej strefy ekonomicznej. Do połowy 2001 r. do katowickiej strefy napłynął kapitał w wysokości blisko 4 mld zł w formie zagranicznych inwestycji bezpośrednich (tab. 3). Wśród inwestorów zagranicznych dominuje kapitał amerykański, który ulokował w strefie 1,9 mld zł, co stanowi 49,1\% wszystkich nakładów inwestycyjnych w strefie. Inwestorzy ze Stanów Zjednoczonych zatrudniają także największą liczbę osób - 4878.

Tabela 3. Bezpośrednie inwestycje zagraniczne w KSSE według kraju pochodzenia kapitału (w tys. zł)

\begin{tabular}{|c|c|c|c|c|c|}
\hline \multirow[b]{2}{*}{ Lp. } & \multirow[b]{2}{*}{$\begin{array}{c}\text { Kraj } \\
\text { pochodzenia }\end{array}$} & \multicolumn{2}{|c|}{ Kapitał zainwestowany } & \multirow[b]{2}{*}{$\begin{array}{c}\text { Liczba } \\
\text { inwestorów }\end{array}$} & \multirow[b]{2}{*}{$\begin{array}{l}\text { Liczba osób } \\
\text { zatrudnionych }\end{array}$} \\
\hline & & $\begin{array}{c}\text { Wartość } \\
\text { skumulowana }\end{array}$ & $\begin{array}{c}\text { Udział } \\
\%\end{array}$ & & \\
\hline 1. & USA & 1910492 & 49,1 & 7 & 4878 \\
\hline 2. & Włochy & 747922 & 19,2 & 9 & 1612 \\
\hline 3. & Japonia & 462414 & 11,1 & 2 & 398 \\
\hline 4. & Niemcy & 343833 & 8,8 & 10 & 1292 \\
\hline 5. & Hiszpania & 105289 & 2,7 & 2 & 470 \\
\hline 6. & Szwajcaria & 103417 & 2,7 & 1 & 48 \\
\hline 7. & Holandia & 74417 & 1,9 & 1 & 50 \\
\hline 8. & Szwecja & 65814 & 1,7 & 1 & 108 \\
\hline 9. & Luksemburg & 37139 & 0,9 & 1 & 115 \\
\hline 10. & Dania & 22775 & 0,6 & 1 & 80 \\
\hline 11. & Czechy & 21099 & 0,5 & 2 & 469 \\
\hline 12. & Francja & 19950 & 0,5 & 1 & 190 \\
\hline 13. & Irlandia & 602849,1 & 0,2 & 1 & 74 \\
\hline
\end{tabular}

Źródło: Opracowanie własne

Drugie miejsce pod względem zainwestowanego kapitału w KSSE zajmują Włochy. Kraj ten ulokował w strefie kapitał o wartości $748 \mathrm{mln}$ zł, czyli prawie trzy razy mniej niż USA. Największą włoską inwestycją jest firma Power Train produkująca silniki samochodowe. Pozostałe włoskie inwestycje to wartości rzędu 57-24 mln zł. Kraj ten zajmuje również drugie miejsce pod względem liczby personelu (tab. 3).

Japonia jest krajem, który na terenie strefy ulokował zaledwie dwie inwestycje, spośród których czołowe miejsce zajmuje inwestycja typu greenfield firmy Isuzu Motors i niewielka inwestycja $(10 \mathrm{mln}$ zł) firmy Toyo Seal. Skumulowana wartość kapitału tych inwestycji wynosi $632 \mathrm{mln}$ zł i zapewnia Japonii trzecie miejsce w rankingu krajów pod względem zainwestowanego kapitału w strefie.

Niemcy na terenie KSSE ulokowali dziesięć inwestycji. Kapitał jaki został przez ten kraj zainwestowany to kwota 344 mln zł, co stanowi 8,8\% całego kapitału zagranicznego w strefie katowickiej. Największą niemiecką inwestycją (150 mln zł) jest Ekocem produkujący materiały budowlane. Mimo niższego zainwestowania kapitału Niemcy zatrudniają trzykrotnie więcej pracowników w porównaniu z inwestorami japońskimi. 
Hiszpania i Szwajcaria to dwa kraje, których wartość zainwestowanego kapitału nieznacznie przekracza $100 \mathrm{mln}$ zł, natomiast wartość inwestycji pozostałych siedmiu krajów nie przekracza kwoty $100 \mathrm{mln}$ zł. Mowa o inwestorach z: Holandii, Szwecji, Luksemburga, Danii, Czech, Francji oraz Irlandii (ryc. 2).

Rys. 2. Kraj pochodzenia inwestycji zagranicznych według zainwestowanego kapitału

Przedstawione przykłady inwestycji zagranicznych w woj. śląskim wskazują na znaczne zaawansowanie procesu włączania się Śląskiego w światową produkcję. Odbywa się to za pośrednictwem firm globalnych, które kupując bądź budując nowe zakłady w województwie, włączają je w światową sieć powiązań. Nie obejmuje to jednak wszystkich dziedzin wytwórczości, a ogranicza się do gałęzi o charakterze rynkowym. Minimalne są powiązania ze światowymi producentami tradycyjnych gałęzi przemysłu, zwłaszcza górniczego i hutniczego. Wśród światowych firm, które zainwestowały w woj. śląskim brak jest firm reprezentujących przemysły wysokich technologii (tab. 4).

Tabela 4. Transnarodowe korporacje inwestujące w przemysł woj. śląskiego $\mathrm{i}$ ich pozycja w światowym rankingu firm

\begin{tabular}{|c|l|l|c|l|}
\hline Miejsce & \multicolumn{1}{|c|}{$\begin{array}{c}\text { Nazwa } \\
\text { korporacji }\end{array}$} & $\begin{array}{c}\text { Kraj } \\
\text { pochodzenia }\end{array}$ & $\begin{array}{c}\text { Wartość rynkowa } \\
\text { (mld USD) }\end{array}$ & $\begin{array}{c}\text { Branża } \\
\text { zainwestowania }\end{array}$ \\
\hline 12 & Coca-cola & USA & 138,00 & spożywcza \\
32 & Pepsico & USA & 91,90 & spożywcza \\
50 & Unilever & Holandia, & 64,29 & spożywcza \\
& & Wielka Brytania & 34,84 & motoryzacja \\
218 & General Motors & USA & 19,49 & spożywcza \\
245 & Danone Group & Francja & 16,85 & spożywcza \\
274 & Seineken & Holandia & 15,30 & szklarska \\
289 & Alcatel & Francja & 14,52 & gazy techniczne \\
302 & L’air Liquide & Francja & 14,14 & gazy techniczne \\
410 & Air Products & USA & 10,92 & gazy techniczne \\
418 & ABB & Szwajcaria & 10,80 & aparatura elektrycz- \\
446 & Henkel & Niemcy & 9,87 & na \\
486 & Proxair & USA & 9,14 & chemia gospodarcza \\
505 & Delphi & USA & 8,83 & chemiczna \\
529 & Thyssen Krupp & Niemcy & 8,34 & motoryzacja \\
578 & BOC Group & Wielka Brytania & 7,73 & profile metalowe \\
\hline
\end{tabular}




\begin{tabular}{|l|l|l|l|l|}
\hline 658 & Fiat Group & Włochy & 6,72 & gazy techniczne \\
677 & Heineken & Holandia & 6,41 & motoryzacja \\
726 & Linde & Niemcy & 5,91 & spożywcza \\
838 & AtlasCopco & Szwecja & 4,94 & gazy techniczne \\
& & & budowlana \\
\hline
\end{tabular}

Źródło: „Business Week” sierpień 2000

\section{Literatura}

Domański B., 2001, Kapitał zagraniczny w przemyśle Polski, Kraków

Fiat 100 lat później, „Illustrato” - numer specjalny lipiec 2001

Giddens A., 1997, Consequences of Modernity, Cambridge

Jubileusz, 5-lecia KSSE, Informator KSSE, kwiecień/maj 2001

Kołodko G., 2001, Moja globalizacja czyli dookoła świata i z powrotem, Toruń

Stryjakiewicz T., 1999, Adaptacja przestrzenna przemystu $w$ Polsce $w$ warunkach transformacji, Poznań

Thurow L., 1998, Przyszłość kapitalizmu, Wrocław

Zorska A., 1998, Ku globalizacji? Przemiany $w$ korporacjach transnarodowych $i w$ gospodarce światowej, Warszawa 